\title{
VÄHEMUSKEELTE ELUJÕULISUS JA ARENGUSUUNDUMUSED EESTI VENEKEELSETES KEELEKESKKONDADES
}

\section{Elvira Küün}

Ülevaade. Artiklis on kirjeldatud vähemuskeelte situatsiooni Eesti venekeelsetes keelekeskkondades. Vaatluse all on informantide eelistatavad keeled nii kodus kui ka väljaspool kodu ning lugemisel. Eesmärk on anda ülevaade vähemuskeelte elujõulisusest, järjepidevusest ja arengust mitme põlvkonna vältel. Ühtlasi on eesmärgiks Eesti eri keskkondades tarvitatavate keelte kasutamise kaardistuse põhjal luua andmebaas nende piirkondade vastavate keelekeskkondade kohta ning andmestu tutvustamine. Segregatiivsete keelekeskkondade andmebaasi kaudu saab ülevaate, mis alustel toimub üldiselt keele-eelistus, millest on tingitud mingi keele dominatsioon teiste keelte üle, mis keeli kasutatakse segregatiivsetes keelepiirkondades eri valdkondades kodus, koolis ja mujal. Samuti on andmebaasis kirjas, mis tasemel vallatakse kasutatavaid keeli. Antud uurimus võib saada oluliseks lähteallikaks segregatiivsete keelekeskkondade keelekõnelejate haridusvajaduste määramisel ja sellega seoses ka vastavate haridusotsustuste mõjutamisel Eesti haridusmaastikul.

Uurimuse läbiviimise meetodina on kasutatud kirjalikku küsitlust ja intervjuud.*

Võtmesõnad: hariduspoliitika, keelepoliitika, keelevalik, keelepädevus, kodukeel, eesti keel, vene keel, teised keeled

\section{Sissejuhatuseks}

20. sajandile üks iseloomulikumaid jooni on rahvaste migratsioon üle rahvuslike ja geograafiliste piiride. Paljusid maailma kultuure ja keeli - eriti neid, mis on arvuliselt väiksemad - ähvardab sulandumine teistesse, domineerivatesse keeltesse ja kultuuridesse. Tuhanded keeled on paari viimase sajandi jooksul juba kadunud.

* Käesolevat uurimust on rahastanud riikliku programmi “Eesti keel ja kultuurimälu 2009-2013” (EKKM09-186) 
Maailmas valitseb tendents, kus surve muutuda homogeenseks puudutab nii rahvuslikku assimilatsiooni kui ka majanduslikku üleilmastumist (Edwards 1996).

On arvatud, et 21. sajandil tabab 90\% keeltest keelesurm (Krauss 1992). Keelesurm on keelevahetuse viimane staadium, mis saab alguse sihtkeelekõnelejate arvu vähenemisest, mis toob endaga kaasa keeleoskuse kadumise või selle tarvitamise kahanemise eri valdkondades (Baker 2006: 75). Keele säilitamine aga tähendab keele jätkuvat võitlust regionaalselt ja sotsiaalselt võimsama keelega (ibid.). Keelte saatust mõjutavad erisugused makro- ja mikrotasandi mõjurid. Conklin ja Lourie (1983) on välja pakkunud järgmised poliitilised, kultuurilised ja keelelised tegurid, mis aitavad keelt kas säilitada või välja tõrjuda.

1) Poliitilised, sotsiaalsed ja demograafilised tegurid:

- sidepidamine kodumaaga ja kodumaa külastamine;

- etnilise grupi identiteedi säilitamine enamusgrupi identiteedi omaksvõtu asemel;

- suhtlusvõrgustike roll keele säilitamisel või keelevahetusel.

2) Kultuurilised tegurid:

- eksisteerivad emakeelsed institutsioonid (s.o koolid, kogukonna organisatsioonid, massimeedia, vabaaja tegevused);

- kultuuritegevused ja religioonilised kombetalitused viiakse läbi oma kodukeeles;

- etniline identiteet on tugevalt seotud kodukeelega;

- üksikindiviidist lähtuvad keelehoiakud ning suhtumine päritolukeelde ja -kultuuri.

3) Keelelised tegurid:

- emakeel on standardiseeritud ja eksisteerib kirjalikus vormis;

- kodukeelel on rahvusvaheline staatus;

- on olemas emakeelne kirjaoskus, mida kasutatakse kogukonnas ja kodumaal.

Keel võib kaduda väga kiiresti, kui seadus keelab seda koolis kasutada ning olukorras, kus kodune keeleülekande mehhanism enam ei toimi. Keele taastähtsustamine kooli kaudu on väga aeglane protsess. Keelekasutuse vähenemine võib aega võtta vaid paarkümmend aastat, keele taassündimiseks läheb palju rohkem aega (Baker 2006). Keele taassünd hariduses ei alga väikestest koolilastest, vaid vajab õpetajate valmidust ja vastavat väljaõpet - õpetajad peavad tegema lapsevanemate ja keelekorraldajatega koostööd, et keelt päästa. Hyltenstam ja Stroud (1996) lisavad, et analüüsides keelevahetust, on sotsiaalse ja keelekõnelejate kogukonna dimensiooni kõrval väga tähtis ka individuaalne, isiklik tasand vähemuskeele säilitamisel (selle esindajate suhtumine päritolukeelde).

On leitud, et kui on loodud võimalus saada haridust oma päritolukeeles, siis suurenevad inimese eneseaustus ja keeleteadmised, samuti paranevad intellektuaalsed võimed (Baker, Jones 1998: 517). Alternatiivselt on arvatud, et kus võimalik, peaks koolisüsteem piisavalt paindlikult liitma endaga vähemusgruppide kodukeele ja kultuuri (ibid.). 


\subsection{Keelevähemuste keeleline identifikatsioon}

Emakeelel on tugev mõju lapse keelevalikule, isa esimesel keelel selles tavaliselt nii suurt osa pole leitud (Bayley, Schecter 2003: 18), kuigi samas ei pea ema- ja kodukeel tingimata ühtima (Baker, Jones 1998). Terminit kodukeel on mõned lingvistid eelistanud märkimaks iseloomulikke dialekte ja keeli, mida kasutatakse sageli ainult kodukontekstis ja neid keeli võidakse paljudel juhtudel järgmistele põlvkondadele edasi anda ainult suulise pärimusena (Moon jt 2000: 775).

Keelevähemusi aga võib määratleda kui üksikisikuid, kelle kodudes kasutatakse aktiivselt enamkasutatavast erinevat keelt ja kellel seepärast on olnud võimalus tõsta oma keelepädevuse taset selles keeles (Goldenberg jt 2006: 21). Domineerivaks keeleks on nimetatud keelt, milles on keelekõnelejal kõige paremad teadmised või mida ta kõige rohkem kasutab (Baker, Jones 1998).

Et keel esindab ja vahendab otsustavat elementi inimese sotsiaalses identiteedis, sellele on osutanud mitu uurijat (nt Hoffmann, Ytsma 2003, Skutnabb-Kangas 2000, Iskanius 2005, Ü. Rannut 2005). Vähemusgruppide keeleidentiteeti on vaadeldud kui mitteametliku keele omaksvõttu emakeelena või kodukeelena ( $\mathrm{Li}$ 2001: 137). See ei tähenda seda, et need, kes samastavad end mitteametliku keelega kui ema- või kodukeelega, tunnevad tingimata tugevat kuuluvustunnet sellesse gruppi (ibid.).

Tööturg on keelevahetuse ja -hoiakute üks tugevamaid mõjutegureid, mis mõjutab ka keelelisi valikuid ning sellega koos ka keelelist identiteeti (Iskanius 2005). Shapiro ja Stelcner (1997) on väitnud, et harilikult kalduvad uusimmigrandid, tulles sihtmaale, alguses kas ainult või sagedamini kasutama oma emakeelt, misjärel aja möödudes hakkab see tendents muutuma. Järelikult tuleb tõdeda, et valitsev tööturusituatsioon ei aita vähemuskeelte säilitamisele kaugeltki kaasa. Teine oluline tegur on perekond: nendel etnilistel gruppidel, kes rõhutavad peresidemeid, paistab olevat tugev mõju oma laste hoiakutele õppida ja kasutada nende enda etnilist keelt kodus (Gans 1997).

Keel on kultuuri kandjaks, seepärast on keelelisel identiteedil oluline osa etniteedi moodustumisel (Skutnabb-Kangas 2000). Ühise keeleruumi kaudu ühtlustub identiteet, kuid osa kollektiive on kakskeelsed, kus kõneleja valib keele olenevalt olukorrast või valdkonnast (diglossia, vt Vahtin 2004). Näiteks keelekogukond võib kasutada vähemuskeelt kodus, naabruses, religioossetel eesmärkidel ja sotsiaalsetes tegevustes, kuid samas enamuskeelt töökohal, hariduses ja massimeediat tarbides (Hudson 2001). Harilikult on enamuskeel kasutusel ametlikus suhtluses ja vähemuskeel mitteametlikus (Baker 2006). See kontrast kõrge ja madala ühiskondliku staatusega keele vahel võib olla tingitud pigem keeleprestiižist ja keelevõimust, mitte keelevariatiivsusest (ibid.).

Väga oluline on suhe keelevaliku ja identiteedi vahel. Mingi keele valimine markeerib teatud identiteeti ja võib otsustada isegi seda, kas indiviid võetakse mingisse gruppi vastu või mitte. Inimesed on keelevalikuga samal ajal silmitsi ka oma identiteedi või kogukonna valikuga (Mills 2001: 400). 


\subsection{Vähemusrühmade etnolingvistiline vitaalsus}

Keelekontaktide situatsioonis saame mis tahes keele puhul rääkida keelelisest lojaalsusest (Fishman 1991). Keelekontakt on alati olemuselt unikaalne ja seda hinnatakse selle karakteristikute ja dünaamilisuse põhjal. Teiseks, tähtis on arvestada sotsiaalpsühholoogilisi faktoreid, mis võivad mõjutada või kujundada keelelojaalsust, nagu ka väljastpoolt tulenevad, objektiivsed tegurid (Komondouros, Mcentee-Atalianis 2007). Keelt on sageli vaadeldud kui lojaalsuse tundemärki, sümbolit, millesse suhtutakse kui mingi rahvuse hulka kuulumise tähistajasse (Baker 2006). Etnolingvistilise vitaalsuse probleeme on Eesti tingimustes uurinud nt ka Martin Ehala, Anna Verschik, Kadri Koreinik, Karl Pajusalu jt.

Etnolingvistilise vitaalsuse kontseptsioon rõhutab, et individuaalse keelevaliku sotsiaal-psühholoogilised aspektid ja assotsiatsioonid on seotud väliste mõjuritega, mis on sotsioökonoomilised, geograafilised ja poliitilised keelekontakti situatsioonis (Giles jt 1977). Etnolingvistilist vitaalsust on defineeritud kui midagi, mis paneb inimrühma käituma end teistest eristavalt ja rõhutama kollektiivset identiteeti rühmadevahelistes dialoogides (Giles jt 1977: 308). Seda saab hinnata kolme aspekti järgi: staatus, demograafia ja institutsionaalne toetus (ibid.). Gilesi ja Byrne’i (1982) järgi sisaldab etnolingvistiline vitaalsus järgmisi aspekte:

1) etnilise rühma majanduslik, ajalooline, sotsiaalne, poliitiline ja keeleline staatus;

2) etnilise grupi suurus ja levik, segaabielud;

3) institutsionaalne tugi etnilistele rühmadele (s.o meedia, haridus, tööstus, religioon, teenused, kultuur ja riigivalitsemine).

Bakeri ja Jonesi (1998) järgi tähendab keelevitaalsus seda määra, mille piires keelevähemused jõuliselt säilitavad ja laiendavad oma igapäevase keele kasutamist ja korrastavad selle funktsioone. Keele elujõulisuse määramisel on olulised selle keele staatus, institutsionaalne toetus, majanduslik väärtus ja seda keelt kõnelejate arv ja levik. Keelelojaalsus peegeldab individuaalseid ja sotsiaalseid jõupingutusi säilitada etniline identiteet sünni- või pärandkeele jätkuva kasutamise abil (Wiley 1996), lojaalsus mingile keelele on selle säilitamise vahend.

Tegelikkuses võivad indiviide survestada kodukeelt vahetama domineeriva enamusrühma keele vastu mitu tegurit, mis võivad olla nii positiivsed (s.o tugev soov assimileeruda riigikultuuri või suurendada enda kultuurilist või majanduslikku kapitali) kui ka negatiivsed (s.o reaalne ja tajutud diskrimineerimine, keelepoliitika, mis teeb kohustuslikuks ametliku keele ja kitsendab domineerivast keelest erinevate keelte kasutust). Uurijad (nt Urzúa, Gómez 2008) on toonud välja, et keelevahetus kaldub kiirenema, kui hoiakud pärandkeele suhtes on negatiivsed (s.o pärandkeelele on omistatud väike väärtus) ja kui pole piisavalt võimalusi sotsiokultuuriliseks keelekaitseks. Mis tahes jõud selle taga ka pole, viib keelevahetus tavaliselt keelekaoni nii üksikindiviidide puhul kui ka rühma sees.

Kogukondades, kus on indiviididel tugevad sotsiaalsed võrgustikud, positiivsed vaated kogukonna keelele ja täpselt ära määratud kodukeele kasutamise reeglid, on keelemuutuste protsess aeglane, võttes aega umbes neli põlvkonda (Holmes, Aipolo 1993). Kogukondade ja indiviidide seas aga, kus võrgustikud on nõrgad, on hoiakud keele alalhoidmise suhtes ambivalentsed ning seega võib ühiskonnas domineeriv keel muutuda kodus kasutatavaks keeleks, lisaks on keelemuutus 
kiire ning võib toimuda isegi vähem kui kahe põlvkonna jooksul (Starks 2005: 541). Põlvkondadevaheliseks keelesäilitamiseks on vajalik kasutada vähemuskeelt perekonnaringis, sest keelel, mis on õpitud kodus, on parimad võimalused säilida ka väljaspool koduseinu (Broeder, Extra 1999).

\subsection{Vähemuskeelsete laste õpe: koolikeskkond ja vastutus}

Lapsed, kellel on enamikust erinev etniline tagapõhi, võivad end leida kahe kultuuri vahelt, kus nende identiteet on väga tugevalt seotud nende keelevalikuga. See võib teha neid koolis oma kodukeele kasutamise suhtes tõrksaks, juhul kui neid pole kindlustatud tõeliselt mitmekultuurilise koolikeskkonnaga (Siraj-Blatchford, Clarke 2000: 29). Pedraza ja Pousada (1992: 253) järgi sõltuvad lapsed omavahel võistlevatest mõjudest, mida avaldatakse neile kodust, koolist ja kogukonnast. Kaasamise mõistega toonitatakse seda, et kohandumisele kaasaaitamine kuulub kooli vastutusalasse: kool peab muutma oma keskkonda ja poliitikat, et mahtuda õpilaste vajadustesse (DfEE 1999).

Maailmas on loodud vabatahtlikkuse alusel moodustatud keeleklasse kooliealistele lastele. Kui kool ei toeta immigrantide vähemuskeele õpet, siis võib keele n-ö taastootmine olla mitteküllaldane selleks, et vähemuskeel säiliks. Seepärast on kohalikud kogukonnarühmad loonud võimalusi andmaks oma lastele vastavat koolitust. Näiteks Inglismaal ja Kanadas on moodustatud vähemuskeele klasse, õhtukoole, koolivaheajal töötavaid õpperühmi, laupäeva-ja pühapäevakoole erinevatele kogukondadele selleks, et õpetada lastele nende vanemate ning vanavanemate keelt ja kultuuri (Baker 2006: 125-126). Sarnane vabatahtlik tegevus võib olla samas ka religioosse, kultuurilise, sotsiaalse, integratiivse ja etnilise vähemuse elujõulisuse tugitalaks (ibid.). Eksisteerivad aga ka ametlikult kakskeelse õppeprogrammiga koolid, kus ühel päeval kasutatakse ühte keelt ja teisel teist, ning leidub ka selliseid õppeasutusi, kus kasutatakse õppekeelena pool päeva ühte keelt, päeva teisel poolel aga teist keelt (Baker, Jones 1998: 588).

On leitud, et süstemaatiline kodukeele õppekeelena kasutamine eelkoolieas toetab hilisemat akadeemilist võimekust ja avaldab positiivset mõju ka kooliealistele lastele, kui nad õpivad kakskeelsete õppeprogrammide järgi (vt nt Kohnert jt 2005: 257). Lõppkokkuvõttes on lapsevanemate võimuses julgustada ka esimest keelt omandama, seda edasi arendama ja säilitama ning ka kirjalikus vormis edasi andma (Seville-Troike 2000: 165). On oluline uurida, millised perekonna keelepoliitika komponendid, nagu ka sotsiolingvistilised tegurid, võivad kiirendada või aeglustada kodukeele alalhoidu.

\subsection{Informaalne keeleplaneerimine}

Palju on diskuteeritud selle üle, kas üldse on vaja toetada kodukeele arengut, kui see pole enamuskeel ja seda ei kasutata haridussüsteemis. Süstemaatilise keelekõnelemise võimaluse andmise positsioon on motiveeritud ja seotud lapse sotsiaalse, emotsionaalse ja kognitiivse arenguga perekonna kultuurikontekstis (Tuijl jt 2001). Sotsiaalsete, emotsionaalsete, kognitiivsete ja kommunikatsiooni- 
oskuste areng on lastel vastastikku sõltuv. Need üksteisega suhestuvad oskused arenevad kultuurikonteksti sees ja primaarne kultuurikeskkond ongi lapse jaoks vahetu perekond (Kohnert jt 2005).

Alternatiivne perspektiiv kodukeele säilitamiseks on keelestrateegia, kus lapsevanemad kasutavad oma lastega suheldes aktiivselt oma vähemuskeelt (Goldenberg jt 2006). Üks põhjus võib selleks olla, et kindlustada parim võimalik lingvistiline mudel laste jaoks. On täheldatud, et ühes keeles omandatud oskused ja teadmised kanduvad üle teise keelde (Wong Fillmore 1991). Teine põhjus esimest keelt kodus säilitada on selle olulisus kultuurilistel, kognitiivsetel ja pragmaatilistel põhjustel, mis moodustab omakorda olulise osa kultuuripädevusest (Simpson 1991). Pole aga selget vastust küsimusele, mis keeles peaks kodus püüdma laste kirjaoskuse arengut ergutada.

Piller (2002: 62) viitab samuti mitteametlikule keeleplaneerimisele ning toob välja, et paljud abielupaarid ei tee teadlikku otsust, mis keelt peaks kodus kasutama, seega on keelevalik juhuslik. Samas aga leidub ka neid, kes hoiavad teadlikult kahte keelt eri situatsioonide puhul lahus ja määravad ära täpsed strateegiad, mis keeles rääkida nii omavahel kui ka lastega. Pavlenko (2004: 184) toob samuti välja, et lapsevanemad teevad keelevalikuid perekonnas kas teadlikult, alateadlikult või spontaansete otsuste põhjal. Vanemate keelevalikule avaldavad mõju nii sotsiaalne kontekst, milles perekond asub, kui ka lokaalne kontekst (nt kogukonna keele-eelistus). Oma lastega suhtlemiseks võivad lapsevanemad valida mõlemad ühe kindla keele. Teisel juhul võib aga ema valida lapsega suhtlemiseks ühe keele, isa teise keele. Paljud pered säilitavad tasakaalu kahe keele vahel, näiteks vanemad räägivad omavahel ühes kindlas kokkulepitud keeles, lastega rääkides aga kasutatakse teist või isegi kolmandat keelt. On registreeritud juhtumeid, kus keel ja keelestrateegia perekonnas valitakse lähtuvalt emotsioonidest, näiteks võidakse ühes keeles väljendada positiivseid, teises negatiivseid tundeseisundeid (Pavlenko 2004).

On avastatud, et lapsed ise võivad üllatavalt tugevalt oma keelevalikut juhtida (Tuominen 1999). Samuti näitab laps üles valmidust kasutada kahte keelt paralleelselt. Koodivahetus, milleks on keelevariandi vahetamine ühe lause sees või lausete vahel (Verschik 2004), leiab tavaliselt aset informaalses suhtlusolukorras (Zentella 1999). Ka lapsevanemad kasutavad aeg-ajalt koodivahetust, näiteks kui ei suudeta meenutada sõna või fraasi ühes keeles. Täiskasvanute puhul aga võib koodivahetusel ja koodivaheldamisel olla ka pragmaatilisi eesmärke, näiteks käsu tugevdamiseks (Kaur, Mills 1993). Muuhulgas on tehtud tähelepanekuid, et vähemusrühmade seas kasutatav koodivahetus on sisuliselt samm enamuskeelse keelevariandi suunas (Baker, Jones 1998: 587).

Vähemuskeelsete laste kodukeele tase koos selle sotsiaalsete, emotsionaalsete ja kultuuriliste lülidega on paraku ohus ka vastavate keelte kodus suhteliselt aktiivsel kasutamisel. Võime säilitada ja arendada oskusi vähemuskeeles peab olema vastavuses kooli süstemaatilise toetuse ja rikastamisprogrammidega kodukeeles. Kui kavandatud tugi kodukeele jaoks pole kättesaadav, siis soovivad vähemuskeelsed lapsed tõenäoliselt palju vähem kasutada oma vanemate ja teiste lähedaste pereliikmetega suheldes oma kodukeelt (Anderson 2004). Järelikult suureneb sellega seoses nende laste jaoks koormus nende sotsiaalsele, emotsionaalsele ja akadeemilisele arengule. 


\section{Vähemuskeelte uuringu tähtsus Eesti kontekstis}

Eesti kui Euroopa Liidu liikmesmaa jaoks on oluline välja selgitada, milline on praegune reaalne keelesituatsioon ja mis keeli Eesti elanikud kasutavad - see lähtub Euroopa Liidu keelepoliitikast, mis propageerib mitmekeelsust (Commission ... 2005). Samavõrra tähtis on järele uurida eri keelte tõeline keelekasutuse ulatus ning keelte varieeruvus avalikus ja erasfääris. Toetudes Euroopa konventsioonile (2003), peab Euroopa Liit aktsepteerima mis tahes kultuurilisi, religioosseid ja lingvistilisi erinevusi (Baldauf, Kaplan 2006).

Vastavalt 2000. a rahva- ja eluruumide loenduse andmetele elab Eestis 142 etnilise rühma esindajaid, kes kõnelevad kokku 109 emakeelt (Eesti ... 2000). Need registriandmed näitavad, mis keeli väidetakse olevat emakeel. Selgusetu on aga see, mis keeli ja keelevariante kasutatakse kodus kui erasfääris.

Uurides kodu- ja vähemuskeeli, võib saada olulist lähtematerjali hariduspoliitikale, et aidata planeerida kodukeele õpet - igal inimesel on ju õigus oma emakeelele. Oma keele ja kultuuri väärtustamine kujundab ka positiivset suhtumist sihtkultuuri. Eestis on praegu 21 pühapäevakooli (Muldma 2009), kus õpetatakse Eesti vähemuskeelsetele lastele nende päritolumaa keelt ja kultuuri. Kõige selle juures aga säilib ikkagi oht, et keel kas hääbub või sureb. Selle põhjuseks on sageli just kultuurisurve ja keele prestiiži langus kõnelejate endi silmis. Alati ei olegi selle puhul määrav keelekõnelejate arv, põhiline on siiski suhtumine (M. Rannut jt 2003).

\subsection{Uuringu eesmärk ja meetodid}

Uuringu eesmärk oli välja selgitada, mis keeled on uuritavates venekeelsetes keelekeskkondades kasutusel kodus ja koolis, mis tasemel vallatakse vastavaid keeli, mis on keelevaliku ja -eelistuse aluseks ning missugune on keelerepertuaar nii koolis kui ka kodus. Ühtlasi uuriti informantidest lastevanemate arvamust selle kohta, kas nemad sooviks, et koolis õpetataks nende vähemuskeelset päritolukeelt. Uuringud korraldati Eesti linnades, mida iseloomustab nende mitmekeelne ja -kultuuriline rahvastik.

Kohtla-Järve linnas viidi läbi kvantitatiivne uurimus, Maardu linnas kasutati lisaks kvalitatiivset meetodit. Maardu puhul olid kooliõpilaste kõrval informantidena kaasatud ka nende vanemad, kelle kaudu omakorda saadi informatsiooni ka nende vanemate kodukeelte kohta. See võimaldas uurida keeleülekannet mitme põlvkonna vältel ja seega vähemuskeelte elujõulisust pikemal ajavahemikul. Uuringu ühe eesmärgina püüti ühtlasi välja selgitada koolides õpetatavad keeled ning välja uurida, kas selgub vajadus õpetada peale nende veel muid keeli. Üks eesmärk oli vaadelda ka keelevähemuste etnilise identiteedi säilimist või muutumist pikema aja vältel ning võrrelda nende kahe uuringu tulemusi Tallinna linnas korraldatud kodukeelte uurimusega (vt Ü. Rannut, M. Rannut 2007).

Uurimismeetodina kasutati anketeerimist ja intervjuud. Anketeerimise abil saadi informatsiooni muuhulgas õpilaste ja nende vanemate päritolumaa kohta, samuti kodukeele kasutuse ulatuse, kodukeele pädevuse ja suhtluskeele valiku kohta pereliikmetega. Uurimise all oli ka õpilaste keele-eelistus väljaspool kodu. Uuritava keelerepertuaari moodustasid ühtlasi koolis õpitavad keeled. Käesoleva 
andmebaasi abil saab iga keelerühma kaupa eraldi oletada nende elujõulisust ja kestust põlvkondade lõikes.

Statistiliseks töötluseks kasutati statistilist andmetöötluspaketti SPSS 13.0. Kasutati korrelatsiooni, T-testi ning $\chi^{2}$-testi. Korrelatsiooni eesmärgiks oli välja selgitada, kas kaks tunnust on omavahel seotud või mitte ning kui tugev see seos on. T-test võimaldas kindlaks teha, kas erinevus tunnuste keskväärtuste vahel on oluline või mitte. $\chi^{2}$-testi kasutati üldkogumi puhul, kontrollimaks, kas jaotus on ühtlane.

\subsection{Kahe venekeelse piirkonna areng: Kohtla-Järve ja Maardu linn}

Keelelisest küljest on Eestis küllalt omapärasteks piirkondadeks kujunenud KohtlaJärve ja Maardu linn. Praeguse Kohtla-Järve kohale ei olekski arvatavasti kerkinud linna, kui poleks olnud põlevkivi, mida hakati seal ulatuslikult kaevandama. Põlevkivi baasil arenes välja keemiatööstus. 1947. aastal muudeti Kohtla-Järve vabariikliku alluvusega linnaks, mis tõi kaasa täiendavate investeeringute saabumise sinna (Kohtla-Järve ... 2008). Seoses tööstuse arenguga toimus Kohtla-Järvel pärast II maailmasõda immigrantide sissevool Nõukogude Liidu teistest regioonidest (Helemäe jt 2000: 17). Nii saabus siia kümneid tuhandeid mitte-eestlasi, kellest suur osa siirdus Kohtla-Järvele kui tööstuspiirkonda. Selle tulemusel ongi kujunenud olukord, kus Kohtla-Järve linna rahvastikust enamiku moodustab venekeelne elanikkond (ibid.). Linna elanike arv on natuke üle 50 ooo (Kohtla-Järve ... 2009). Eestlasi oli 2000. a rahvaloenduse andmeil Kohtla-Järve linnas 17,8\%.

Oma arengu poolest on sarnane Maardu linn, mis asub vahetult Tallinnast idas ja kus elab üle 16 ooo inimese. 1939. a loodi riiklik aktsiaselts Eesti Fosforiit uue kaevanduse ja rikastusvabriku rajamiseks ning uus tööstuskompleks. Pärast II maailmasõda jätkati Maardu fosforiiditootmise arendamist - rajati väävelhappetsehh ja superfosfaaditsehh ning samal ajal toimus märkimisväärne mitte-eestlaste sisseränne (Maardu ... 2009). Vaevalt leidub Eestimaal teist samasugust linna nagu Maardu, kus elab nii palju erinevate rahvuste esindajaid. Enamiku elanikkonnast moodustavad venelased, eestlaste protsent on umbes 20\%. Linnas on esindatud 41 rahvust, kes kuuluvad erinevatesse konfessioonidesse (ibid.).

\section{Kohtla-Järve linna keelteuuring}

Küsitlus korraldati kümnes Kohtla-Järve koolis, sihtrühmaks olid 8-12-aastased õpilased (erinevalt Maardust polnud kaasatud lapsevanemaid). Uuringus osales 80,5\% kõigist Kohtla-Järve 2.-5. klasside õpilastest (kokku vastas ankeedile 1002 õpilast, neist 774 õpilast vene ja 228 eesti õppekeelega koolidest).

Uuringus osalenud Kohtla-Järve koolide õpilased on pärit kahest ning nende vanemad 16 riigist (vt tabel 1). Suurem osa informante oli sündinud Eestis: õpilastest peaaegu kõik (99,5\%), emadest oli Eestis sündinuid 82,63\% ning isadest 81,53\%. Venemaal oli sündinud 5 õpilast, emasid põlvneb sealt 12,97\% ja isasid 13,17\%. Seega kuulub suurem osa antud õpilasrühmast teise põlvkonna immigrantide hulka. 
Tabel 1. Õpilaste ja lapsevanemate sünnimaad ${ }^{1}$

\begin{tabular}{|c|c|c|c|c|c|c|}
\hline \multirow[b]{2}{*}{ Sünnimaa } & \multicolumn{2}{|c|}{ Õpilased } & \multicolumn{2}{|c|}{ Emad } & \multicolumn{2}{|c|}{ Isad } \\
\hline & Arv & $\%$ & Arv & $\%$ & Arv & $\%$ \\
\hline Eesti & 997 & 99,5 & 828 & 82,63 & 817 & 81,53 \\
\hline Venemaa & 5 & 0,5 & 130 & 12,37 & 132 & 13,17 \\
\hline Ukraina & & & 15 & 1,5 & 16 & 1,6 \\
\hline Valgevene & & & 13 & 1,3 & 17 & 1,7 \\
\hline Usbekistan & & & 4 & 0,4 & 0 & 0 \\
\hline Kasahstan & & & 4 & 0,4 & 1 & 0,1 \\
\hline Aserbaidžaan & & & 1 & 0,1 & 4 & 0,4 \\
\hline Läti & & & 2 & 0,2 & 2 & 0,2 \\
\hline Armeenia & & & 2 & 0,2 & 3 & 0,3 \\
\hline Türkmenistan & & & 1 & 0,1 & 2 & 0,2 \\
\hline Leedu & & & 1 & 0,1 & 2 & 0,1 \\
\hline Poola & & & 1 & 1,1 & 0 & 0 \\
\hline Tadžikistan & & & & & 1 & 0,1 \\
\hline Taani & & & & & 1 & 0,1 \\
\hline Soome & & & & & 3 & 0,3 \\
\hline Itaalia & & & & & 1 & \\
\hline Kokku & 1002 & 100 & 1002 & 100 & 1002 & 100 \\
\hline
\end{tabular}

\subsection{Sünnimaa ja kodukeele seos}

Õpilaste vanemate sünnimaa ei pruugi tingimata mõjutada kodukeele valikut. Kohtla-Järve õpilased kasutasid pereliikmetega suheldes ainult kas eesti või vene keelt, olenemata vanemate sünnimaast (vt joonis 1). Vene õppekeelega koolide õpilastel oli kodukeeleks vene keel isegi sel juhul, kui vanemad olid sündinud Eestis või mõnes teises riigis.

Sünnimaade järgi suurema rühma moodustanud informantidest, kes olid pärit Ukrainast ja Valgevenest (vt tabel 1), suhtlesid vene keelt kodus kasutavad õpilased nii ema- kui ka isapoolsete vanavanematega vene keeles. Sisuliselt on see märk keelekaost. Teisalt võib see näidata ka vanemate väljarännet Ukraina ja Valgevene venekeelsetelt aladelt. Keelekasutust põlvkonniti võrreldes on näha, et keelevahetus on ilmnenud juba eelmises põlvkonnas. Sellest lähtudes võib väita, et nende rahvuste keeled on Eestis vähemalt selles Kirde-Eesti piirkonnas vene keelde assimileerunud.

Eesti õppekeelega koolide õpilasi oli uuritud õpilaste koguarvust 22,75\%. Nendest rääkis eesti keelt kodukeelena $68 \%$, vene keelt aga $15 \%$ ja nii eesti kui ka vene keelt $16 \%$. Seda võib seletada asjaoluga, et osa venekeelse taustaga lapsi on pandud õppima koolidesse, kus on õppekeeleks eesti keel. Mõnel neist on üks vanem eestlane ning kodukeelena kõneldakse nii eesti kui ka vene keelt.

1 Suurem osa väljatoodud riikidest on endise Nõukogude Liidu vabariigid. Siin ja järgnevas on neid nimetatud 


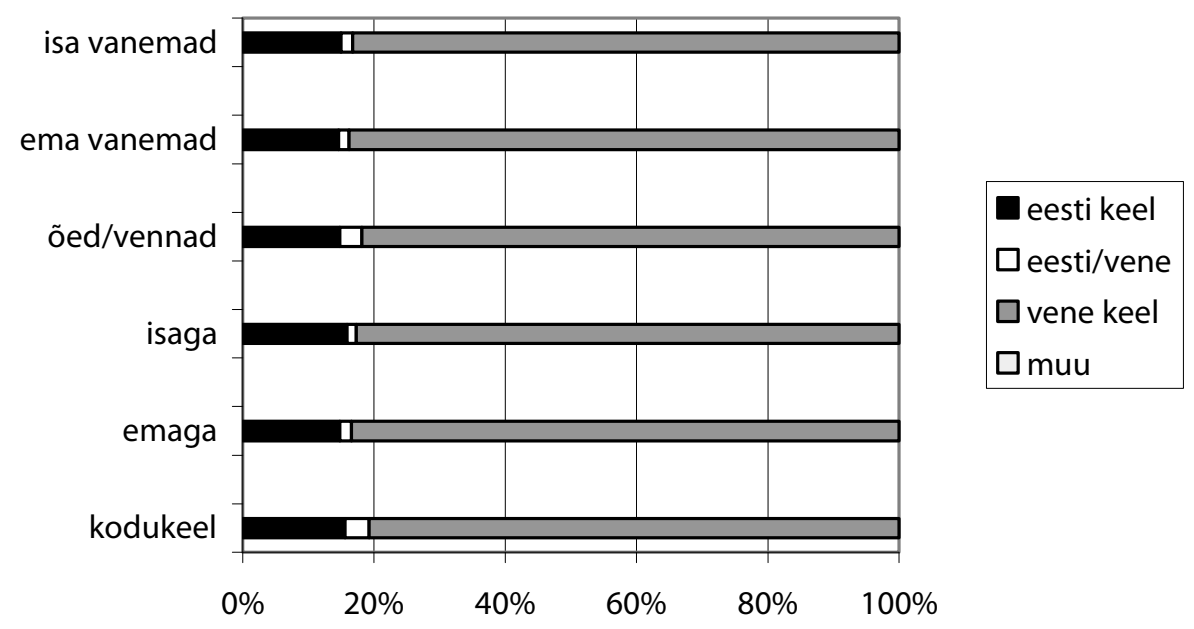

Joonis 1. Kodukeele valik pereringis

Vene õppekeelega koolides õppijad tarvitavad pereliikmetega lävimisel vene keelt. Eesti koolide õpilastest kasutavad eesti keelt emaga suheldes 148, isaga kõneldes 159 ning õdede ja vendadega 148 õpilast. Vene keel on suhtluskeeleks emaga 62 juhul, isaga 55 ning õdede ja vendadega rääkides 46 õpilasel. Nendes peredes on mõlemad vanemad venekeelsed, kuigi lapsed õpivad eesti õppekeelega koolis. Vanemad soovivad nii täiustada oma laste eesti keele oskust ja kiirendada eesti keele selgekssaamist, mis loob paremad eeldused edukuseks hilisemas elus.

Kuna venekeelsete koolide õpilastel on kodukeeleks ainult vene keel, siis statistiliselt analüüsitakse eestikeelsete koolide õpilaste kodukeele ja vanemate sünnimaa seoseid.

Kodukeele seos (korrelatsioon) lapsevanemate sünnimaaga on statistiliselt nõrk. Seda näitavad ka T-testi ja $\chi^{2}$-testi tulemused:

- $\quad$ seos ema puhul: $r=0,21(p=0,004), t=1,846(p=0,66), \chi^{2}=56,12$ $(\mathrm{p}=\mathrm{o}, 000)$;

- $\quad$ seos isa puhul: $\mathrm{r}=0,34(\mathrm{p}=0,001), \mathrm{t}=1,619(\mathrm{p}=0,12), \mathrm{\chi}^{2}=51,27$ $(\mathrm{p}=0,000)$.

Vanavanematega suheldes kasutasid vene koolides õppivad õpilased eranditult ainult vene keelt. Eesti õppekeelega koolide õpilased kasutasid ema- ja isapoolsete vanavanematega suheldes nii eesti kui ka vene keelt. Eesti õppekeelega koolide 146 õpilasel oli emapoolsete vanavanematega kõneldes suhtluskeeleks eesti keel, vene keel aga 66 õpilasel ning nii eesti kui ka vene keelt rääkis nendega 16 õpilast. Isapoolsete vanavanematega kõneldi eesti keelt (150 õpilast), vene keelt (6o õpilast) ja paralleelselt nii eesti kui ka vene keelt (18 õpilast). Juhul, kui vanavanemad olid mingist muust rahvusest kui eestlane, siis oli suhtluskeeleks ainult vene keel. Sellest nähtub, et keelevahetuse protsess on alanud juba varasemas põlvkonnas ning muud keeled on sulandunud vene keelde. Päritolumaa ei mõjuta antud juhul suhtluskeele valikut, kuid seda mõjutab eesti õppekeelega koolides õppijate kodukeel.

Vanavanematega kõneldava keelega on kodukeel statistiliselt tugevas korrelatsioonis: 
- $\quad$ seos ema vanematega: $\mathrm{r}=0,75(\mathrm{p}=0,000), \mathrm{t}=27,75(\mathrm{p}=0,000)$, $\chi^{2}=146,00(p=0,000)$;

- $\quad$ seos isa vanematega: $r=0,77(p=0,000), t=27,65(p=0,000), \chi^{2}=146,00$ $(\mathrm{p}=0,000)$.

Suuruselt kolmas päritoluriik oli Ukraina, ometi ukraina keelt kodukeelena ei kasutatud. See näitab, et ukraina keel on Kohtla-Järve piirkonnas hääbunud. Muuhulgas võib siin leida segaabielude tugevat mõju. Lisaks on immigrandid siia elama asunud ammu, seega pole enam tegemist uusimmigrantidega ning ka see on üks tegur, mis on soodustanud nende venestumist.

Põlvkondadevahelist keelekasutust vaadeldes on näha, et keel on hakanud hääbuma juba varasemas põlvkonnas ja see tendents on põlvest põlve üha süvenenud. Kui leidub piisav hulk õpilasi, kes sooviks vastavat keelt süvendatult õppida, võiks luua kas või valikaine korras koolide juurde õpperühmi, et tõkestada ukraina keele kadumist selles piirkonnas.

Väljaspool kodu kasutasid riigikeelt eesti koolides õppivatest lastest kokku 177, kõik vene õppekeelega koolides õppijad suhtlesid koolis ja sõpradega vene keeles ning lisaks neile kõnelesid 51 eesti koolides õppivat õpilast väljaspool kodu vene keeles, kokku 825 õpilast. Kaasõpilastega lävides oli suhtluskeeleks üldjuhul vene keel, eesti õppekeelega koolides aga 185 juhul eesti keel (eestikeelsetest õpilastest $81,14 \%)$. Sõpradega kõneldes kasutati eesti keelt veel harvem $(15,67 \%$ kogu informantide hulgast). Seega domineerib vene keel märkimisväärselt teiste keelte üle, kusjuures muid keeli informandid väljaspool kodu ei kasutanud.

\subsection{Keelteoskuse tase}

Õppijate keele-eelistust (keele valdamise nelja osaoskuse põhjal) iseloomustavad järgmised asjaolud. Oma emakeelt, mida ei kasutata kooli õppekeelena, oskavad sisserännanud suuliselt paremini kui kirjalikult. Vene õppekeelega koolide lapsed ja eesti koolide eesti taustaga peres elavad õpilased suudavad oma emakeeles hästi ka lugeda ja kirjutada. Seda ei saa öelda eesti koolides õppivate vene õpilaste kohta, kelle kodukeeleks on vene keel: osa neist oskab oma emakeeles lugeda ja kirjutada vaid üsna madalal tasemel. Seda võib seletada asjaoluga, et pereliikmetega suheldes kasutatakse kodukeelt suuliselt, samal ajal kui (eesti) koolis seda ei õpetata või mängivad selle omandamisel rolli muud tegurid. Lugemis- ja kirjutamisoskust emakeeles saaks arendada ka pereringis, kus tulemust mõjutab eelkõige see, mil määral vanemad väärtustavad lapse emakeelt.

Silma torkab ja suunab edasisele arutelule tõik, et Kohtla-Järvel ei toonud uuritud õpilaste hulgast ükski kodus kasutatava keelena välja selle riigi keelt, kust on sisse rännanud nende vanemad (v.a Eesti- ja Venemaa). Kuna kirjaoskuse arendamisel on eriti oluline funktsioon keele säilitamise püüdel, võiks lapsi õpetada nende kodukeeles ka lugema ja kirjutama ning võtta arutluseks nende keelte õpetamise. See toetaks muuhulgas ka teiste keelte õpet ning õpilase positiivse mina-pildi kujunemist.

Kõige paremini vallatavaks keeleks pidasid õpilased vene keelt (1002 informandist 809), vrd eesti keelt oskas kõige paremal tasemel 193 õpilast. Eesti keelt eelistas kasutada 18\%, ülejäänud kasutasid vene keelt (81\%). Seega on nende 
õpilaste keele-eelistuseks vene keel. Peale selle õpib 949 last inglise keelt, saksa keele õppijaid on vähem - 53. Soovitakse kindlasti täiustada oma teadmisi nii eesti, inglise kui ka saksa keeles. Lisaks soovitakse õppida veel ka prantsuse, itaalia, hispaania, soome ja rootsi keelt ning paar õpilast oleks soovinud õppida jaapani ja araabia keelt. Juba I kooliastme õpilaste seas on populaarseks saanud Euroopa Liidu keeled, eriti prestiižseks loetakse inglise ja prantsuse keele tundmist.

\section{Maardu linna vähemuskeelte uuring}

Maardu linnas uuriti vene õppekeelega Maardu Gümnaasiumi algklasside õpilasi ja nende vanemaid. Esiteks anketeeriti neid selleks, et välja selgitada vähemuskeelt kodukeelena kõnelevad õpilased. Teise etapina intervjueeriti neid suuliselt (9 last). Lapsevanemad vastasid oma abikaasade/elukaaslaste ja omakorda mõlema vanemate kohta käivatele küsimustele.

Uuringus osales 177 õpilast (sh 84 tüdrukut ja 93 poissi). Neist 9 lapse kodukeel oli (lisaks vene keelele) mingi muu keel peale eesti keele. Lapsevanemaid osales 152 (sh 133 ema ja 19 isa). Uuringus osalenud informandid on pärit 11 riigist (vt tabel 2). Suurem osa on sündinud Eestis: $96,6 \%$ õpilastest ning isadest $64,9 \%$ ja emadest 60,5\%.

Tabel 2. Õpilaste ja nende vanemate sünnimaad

\begin{tabular}{|c|c|c|c|c|c|c|}
\hline \multirow{2}{*}{ Sünnimaa } & \multicolumn{2}{|c|}{ Õpilased } & \multicolumn{2}{|c|}{ Isad } & \multicolumn{2}{|c|}{ Emad } \\
\hline & Arv & $\%$ & Arv & $\%$ & Arv & $\%$ \\
\hline Eesti & 171 & 96,6 & 107 & 60,5 & 115 & 64,9 \\
\hline Venemaa & 2 & 1,1 & 46 & 25,9 & 41 & 23,1 \\
\hline Ukraina & 4 & 2,3 & 12 & 6,8 & 11 & 6,2 \\
\hline Valgevene & & & 3 & 1,7 & 3 & 1,7 \\
\hline Leedu & & & 1 & 0,6 & 1 & 0,6 \\
\hline Läti & & & 5 & 2,8 & & \\
\hline Kasahstan & & & & & 4 & 2,3 \\
\hline Armeenia & & & & & 1 & 0,6 \\
\hline Ungari & & & & & 1 & 0,6 \\
\hline Kõrgõzstan & & & 2 & 1,1 & & \\
\hline Aserbaidžaan & & & 1 & 0,6 & & \\
\hline Kokku & 177 & 100 & 177 & 100 & 177 & 100 \\
\hline
\end{tabular}

Suurema osa väljaspool Eestit sündinud vanemate päritolumaaks on Venemaa ja Ukraina. Venemaal sündinud isasid ja emasid on vastavalt 46 ja 41 ning Ukrainas vastavalt 12 ja 11. Õpilastest oli Venemaal sündinud 2 last ja Ukrainas 4.

Lapsevanemate rahvusteks olid kolme suurema rühmana venelased (isasid 138 ja emasid 150), ukrainlased (15 isa ja 11 ema) ning valgevenelased (13 isa ja 9 ema). Lisaks oli küsitletute seas 6 eestlasest isa ja 4 ema. Leedulasi oli küsitletud lapsevanemate hulgas 1 (ema), tatarlasi 2 (1 isa, 1 ema), armeenlasi 1 (isa), poolakaid samuti 1 (isa). Lisaks oli informantide seas esindatud 2 soomlast ( 1 isa ja 1 ema). 


\subsection{Sünnimaa ja kodukeele seos}

Maardu õpilased kasutavad 91,5\% ulatuses kodukeelena vene keelt, 8,5\% õpilasi tarvitab kodukeelena vene keele kõrval mingit muud keelt (vt tabel 3). Segaperedes on tavaline, et koduse keelena kasutatakse vene keelt (Ü. Rannut 2002). Kodus kasutatavateks teisteks keelteks on ukraina, leedu, tatari ja eesti keel. Samuti kõneldakse eesti keeles eestikeelse taustaga vanema ja vanavanematega (eesti ja vene keeles segamini), kuid õdede ja vendadega kõnelemisel eelistatakse vene keelt, kuna seda keelt vallatakse kõige paremini. Need vastused on tüüpilised vene keelekeskkonnas viibivatele lastele. Vanemate vastustest selgub, et ka nemad on õppinud vene õppekeelega koolis ning osa neist on sündinud Venemaal.

Tabel 3. Maardu Gümnaasiumi õpilaste kodukeel

\begin{tabular}{|l|c|c|l|}
\hline \multirow{2}{*}{ Keel } & \multicolumn{2}{|c|}{ Õpilased } & \multirow{2}{*}{ Märkused } \\
\cline { 2 - 3 } & Arv & $\%$ & \\
\hline eesti & 6 & 3,4 & 3 ema eestlane, 3 isa eestlane \\
\hline vene & 162 & 91,5 & venelased, valgevenelased, ukrainlased jt \\
\hline ukraina & 7 & 3,9 & 6 ema ukrainlane, 1 isa ukrainlane \\
\hline leedu & 1 & 0,6 & ema leedulane \\
\hline tatari & 1 & 0,6 & mõlemad vanemad tatarlased \\
\hline
\end{tabular}

Vene keele järel moodustab suuruselt teise rühma ukraina keel. Oma teiseks kodukeeleks pidas ukraina keelt 3,9\% õpilastest (7), neist kuuel oli ema ukrainlane, ühel isa. Emadest kõneles ukraina keeles 9, isadest 1. Ukrainas sündinud lapsevanematest kõneles 43,5\% kodus ukraina keeles, kuid teise keelena. Põhikeeleks jäi vene keel. Väljaspool kodu ei kasutanud ukraina keelt ei lapsed ega ka nende vanemad.

Kui võrrelda põlvkondadevahelist keelekasutust, siis võib märgata, et ukraina keele kasutamine on aja jooksul vähenenud. Osa lapsevanemaid (3 ema) oli kõnelenud lapsepõlves oma vanematega ukraina keeles, kuid nad olid õppinud vene õppekeelega koolis, ja oma lastega kõneldakse praegu ainult vene keeles. Suur osa küsitletud Ukrainas sündinud lapsevanematest suhtleb ka oma vanematega vene keeles ( 3 ema ja 10 isa). Võimalik, et ukraina keele toetamiseks oleks vaja õpperühmi või klasse, et takistada ukraina keele lõplikku sulandumist vene keelde.

\subsection{Vähemuskeelte oskuse tase}

Kodukeele pädevust on vaadeldud ukraina, leedu ja tatari keele puhul skaalal arusaamine-rääkimine-lugemine-kirjutamine (vt joonis 2). Ukraina keelest said aru ja oskasid selles keeles end suuliselt väljendada kõik 7 õpilast, lugeda ja kirjutada oskasid nad ainult natuke. Leedu ja tatari keele puhul saadi nendest keeltest aru ja osati neid kõnelda, kuid lugeda ega kirjutada mitte. 


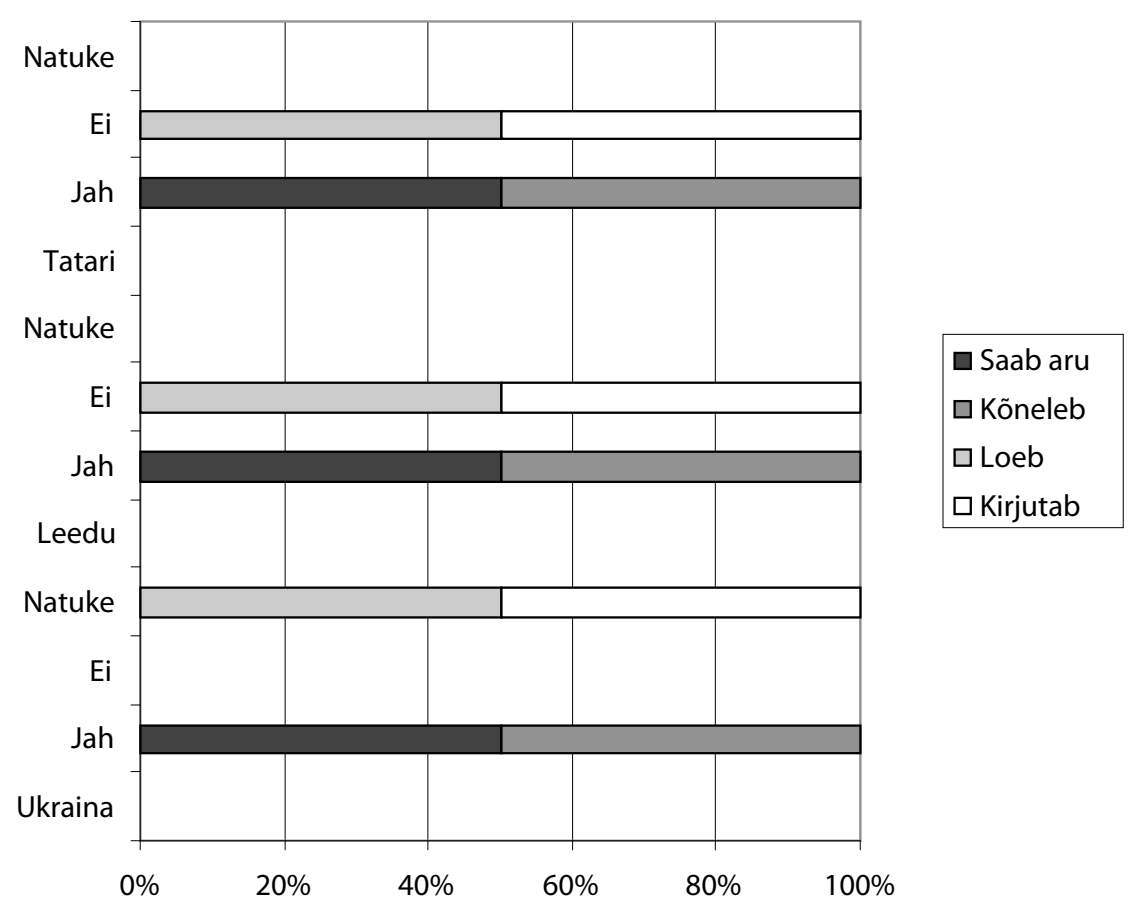

Joonis 2. Vähemuskeele valdamine

Seega on nende kodukeelte suuline oskus (arusaamine ja rääkimine) parem kui kirjalik (lugemine, kirjutamine). See on tingitud sellest, et kodus kasutatakse keelt suuliselt ja neid keeli koolis ei õpetata. Lugemis- ja kirjutamisoskuse tase sõltub põhiliselt sellest, kas keelt koolis õpetatakse, samuti on oluline, kas nende keelte valdamist kõrgemal tasemel peavad lapsevanemad tähtsaks. Keele säilitamise eeldus on kirjaoskus ning seepärast võiks sisse seada teatud keeleõppe tugirühmad, mis aitaksid omandada lugemis- ja kirjutamisoskuse vastavates keeltes.

\subsection{Vajadus vähemuskeelte õppe järele}

Lapsevanematelt küsiti arvamust vähemuskeelsete õpperühmade või klasside vajalikkuse kohta. Vastused olid valdavalt eitavad, kusjuures domineeris praktiline vaatepunkt, näiteks:

- "Eestis elades pole sellist vajadust"

• "Minu laps ei lähe arvatavasti kunagi elama Ukrainasse"

- "Ukraina keel pole Eestis tähtis"

Küsimuse puhul, kas lapsevanemad saadaksid oma lapse õppima, kui lähedal oleks või koolis avataks vähemuskeele õpperühm, vastas üks lapsevanem eitavalt ("Sellel pole mõtet, kuna ukraina kultuur ei erine oluliselt vene kultuurist, seega saab laps vajalikud teadmised kultuurist ja keelest ka vene õppekeelega koolis, ukraina kultuuri võib aga õpetada kodus"), aga ülejäänud pidasid säärase õpperühma avamist heaks mõtteks. Osa lapsevanemaid arvas, et päritolukeelt oleks mõistlik õppida valikaine raames paar korda nädalas. Mõned rõhutasid juurte tundmist, mis toetaks lapse kultuuriidentiteedi säilitamist, ning mõned apelleerisid keeleõigusele - õigusele tunda oma etnilist kuuluvust, kultuuri ja keelt. 
Seega leiab osa Eestis elavaid ukrainlasi, et siin elades ei ole ukraina keel vajalik ega tähtis. Osa arvab isegi, et ukraina kultuur ei erine märkimisväärselt vene omast. Rohkem leidub siiski neid, kes tahavad, et nende lapsed õpiksid tundma oma esivanemate keelt ja kultuuri. Seega oleksid ilmselt vajalikud ukraina keele õpperühmad või -klassid õpilastele, kui leidub vajalik hulk seda õppida soovijaid.

Kodukeelena oli nimetatud ka leedu ja tatari keelt (vt tabel 3). Leedu keele puhul oli ema leedulane (sündinud Leedus), isa aga venelane. Koduse keelena kasutati vene keelt ja teise keelena leedu keelt. Õpilane ja tema isa olid sündinud Eestis. Selle perekonna ema oli oma lapsepõlves koduse keelena kasutanud nii vene kui ka leedu keelt ja õpetas ka oma lastele leedu keelt. Tema laps kasutab ema ja õega suheldes nii vene kui ka leedu keelt. Lapsed kõnelevad ema vanematega leedu ja veidi ka vene keeles, kuid isapoolsete vanavanematega rääkides kasutatakse vene keelt. Küsimusele, mis puudutas leedu keele osaoskuste valdamise taset, vastas õpilane, et saab leedu keelest aru ja oskab seda rääkida, kuid lugeda ega kirjutada ei oska. Siit nähtub, et selles segaperekonnas, kus isa on venelane, kasutatakse kodukeelena vene keelt ja teise keelena leedu keelt. Ühel juhul, kui isa oli leedulane ja ema venelane, kasutati kodukeelena ainult vene keelt. Seega on ema mõju kodukeele valikule antud uurimisaluste puhul suurem kui isal. Leedulasest ema oma lapsi leedukeelse õppega kooli Eestis õppima ei paneks, kuna lapsed valdavad vene keelt paremini ja kodus kõneldakse samuti rohkem vene keeles - seega on lastel kergem õppida vene õppekeelega koolis. Samas oleks ta nõus saatma oma lapse koolis õppima leedu keelt valikainena ("Lapsel oleks vaja teada ka vanavanemate keelt ja kultuuri, kuna see aitab lapsel kultuursemaks inimeseks kasvada ja oma päritolu paremini teadvustada ning selle üle ka uhkust tunda”).

Tatari keel oli küsitletute hulgas esindatud kogu perekonna ulatuses. Mõlemad uuritud vanemad olid tatarlased, kuid sündinud Eestis. Õpilase vanavanemad (nii ema- kui ka isapoolsed) olid tulnud Eestisse tööd otsima 1949. aastal. Vanemad olid õppinud vene õppekeelega koolis, kuid koduseks keeleks kujunes välja vene keele kõrval ka tatari keel. Perekonna ema ja isa kõnelesid oma vanematega nii vene kui ka tatari keeles, samuti suhtles õpilane nii ema, isa, venna ja emapoolsete vanavanematega kui ka isapoolsete vanavanematega vene ja tatari keeles. Selle perekonna puhul on näha, kui hästi on säilinud järjepidevus tatari keele kõnelemisel põlvkondade kaupa. Kaugeleulatuvaid järeldusi ei saa muidugi teha, kuna informantide hulk on väike, ainult 0,6\% selles koolis kõneldavatest keeltest, kuid suundadest annab see siiski aimu.

Tatari keele õppimise kohta arvas lapsevanem, et tatari keelega pole Eestis midagi peale hakata. Kui aga oleks olemas huvialagrupp või avataks vastav valikaine koolis, siis sinna paneks lapsevanem oma lapse õppima, et ta tutvuks tatari kultuuriga ja õpiks tatari keelt, "sest enda päritolu ja juuri tundev inimene on haritud inimene”. Tatari keelest saab uuritud õpilane aru ja ka räägib seda, kuid lugeda ega kirjutada ei oska.

Kahel juhul nimetasid lapsevanemad valgevene keelt ja ühel juhul tšuvaši keelt. Ise olid nad neid kasutanud ainult oma lapsepõlvekodus kodukeelena, nad olid õppinud venekeelses koolis ja venestunud. Oma lastele nad oma keelt enam ei õpetanud, kodukeeleks oli vene keel.

Euroopa Liidu keeltest nimetasid lapsevanemad kahel juhul soome ja ühel juhul poola keelt, milles nad olid lapsepõlves kõnelenud oma vanematega, kuigi olid õppi- 
nud vene õppekeelega koolis. Koduse suhtluskeelena on neil praegu kasutusel vene keel ja oma rahvuseks märkisid nad: venelane. Siin on näha, et keele järjepidevus on kadunud. Lisaks kõneldi väljaspool kodu kõikidel juhtudel vene keeles.

\section{Kohtla-Järve, Maardu ja Tallinna linna õpilaste vähemuskeelte võrdlus}

Uuringus osalenud Kohtla-Järve õpilased on pärit kahest ja lapsevanemad 16 riigist. Suurem osa informantidest on sündinud Eestis. Seega kuulusid õpilased teise põlvkonna immigrantide hulka. Venemaal sündinuid oli 5 õpilast, 130 ema ja 132 isa. Maardu õpilased ja nende vanemad on pärit 11 riigist. Suurem osa informantidest on sündinud Eestis ja enamik õpilastest on seega samuti teise põlvkonna sisserännanud. Võrreldes Tallinnas korraldatud uuringu tulemustega (vt Ü. Rannut, M. Rannut 2007) selgub, et Tallinna õpilased on sündinud koguni 28 ja nende vanemad 52 riigis. Tallinna tööturg on laiem kui kusagil mujal Eestis, sealjuures on see atraktiivsem ka välismaalastele, kelle kodukeel üldjuhul erineb kohalike keeltest.

Sarnaselt Kohtla-Järve venekeelsete koolide õpilastega kasutavad Maardu Gümnaasiumi 2.-5. klasside õpilased domineeriva kodukeelena vene keelt. Maardus oli kodukeeleks vene keele kõrval ka mingi teine keel (ukraina, leedu, tatari ja eesti keel), kusjuures põhikeeleks jäi siiski vene keel. Võrdluseks: Tallinna õpilased kasutasid kodudes 22 keelt (õpilastest pidas teisi keeli oma kodukeeleks 2\%), kusjuures küllalt levinud oli muuhulgas inglise keel, juhul kui mõlemad vanemad või üks neist oli pärit väljastpoolt Eestit. Kolm Tallinna õpilast kasutasid ainsa kodukeelena inglise keelt. Ei Kohtla-Järve ega Maardu õpilaste puhul sellist inglise keele kasutust ei täheldatud, kuigi Kohtla-Järvel oli üks isa pärit Taanist, kolm Soomest ja üks Itaaliast.

Ukraina päritolu lapsevanematest kasutas Tallinnas vaid $7 \%$ kodukeelena ukraina keelt, mis näitab samuti nagu Kohtla-Järve ja Maardu uurimusegi puhul märkimisväärset keelevahetuse määra, mille üheks tõukejõuks võivad olla ka segaabielud. Vastupidise näite võib tuua Tallinnasse elama asunud Aserbaidžaanist pärit perede kohta: 43 lapsevanemast 30 kõneleb kodus aserbaidžaani keeles, mis on suur arv, võrreldes Eestis elava ukraina kogukonna suurusega (Eesti ... 2000). Aseritest uusimmigrandid näivad uude riiki elama asudes väärtustavat oma keelt rohkem kui ukrainlased. Valdavalt on siiski ka Tallinnas, nagu Kohtla-Järvel ja Maarduski, kodukeeleks vene keel, mida kasutab 61\% segaperede õpilasi ja teise keelena 27\% (Ü. Rannut, M. Rannut 2007).

Vanavanematega kõnelesid Kohtla-Järve vene koolide õpilased vene keeles. Eesti keeles suheldi eestlastest vanavanematega. Maardu õpilased kõnelesid vanavanematega samuti vene keeles. Õpilased, kelle vanavanemad olid eestikeelse taustaga, kõnelesid nendega paralleelselt eesti ja vene keeles. Üks Maardu õpilane kasutas vanavanematega suhtlemisel ka leedu ja teine tatari keelt. Kui võrrelda põlvkondadevahelist keelekasutust, võib märgata, et ukraina keele kasutamine on põlvest põlve vähenenud. Keelevahetus ei ole toimunud hiljuti, vaid juba varasemas põlvkonnas. Kui vaadelda mitme põlvkonna vahelist keelevahetust, siis kasutas Tallinnas $80 \%$ vanavanematest lapselastega kõneldes vene keelt. 
Kõigi kolme linna puhul ilmneb, et keelevahetus on toimunud juba eelmises põlves või on väljaränne toimunud Ukraina ja Valgevene venekeelsetest piirkondadest.

\section{Kokkuvõte}

Uurimusest nähtub väga selgelt, et Eesti venekeelsete piirkondade õpilased kasutavad nii kodus kui ka väljaspool peamiselt vene keelt. Vähemuskeelte osaks Eesti segregatiivsetes keelekeskkondades on käesoleva uurimuse põhjal kadumine. Keelevähemused assimileeruvad ja venestuvad.

Keele elujõulisuse ainus mõõt ei ole keelerühma suurus, vaid olulised mõjurid on ka keele staatus, segaabielude mõju keelevalikule jm. Kusjuures määravaks teguriks on inimeste suhtumine oma päritolukeelde. Keelerühmad varieeruvad oma suhtumise poolest - osa vähemusrahvustest väärtustab enda etnilist kuuluvust ja oma päritolukeelt üha rohkem ning püüab teadmisi oma lastele ka edasi anda, hoolitsedes nõnda keele järjepidevuse ja elujõulisuse eest.

Eesti väikekeeled vajavad Eesti keelepoliitika tuge.

\section{Viidatud kirjandus}

Anderson, Raquel 2004. First language loss in Spanish-speaking children: Patterns of loss and implications for clinical practice. - Brian A. Goldstein (Ed.). Bilingual Language Development and Disorders in Spanish-English Speakers. Baltimore: Brookes, 187-212.

Baker, Colin 2000. A Parent's and Teacher's Guide to Bilingualism. 2nd edition. Clevedon, Boston, Toronto, Sydney: Multilingual Matters Ltd.

Baker, Colin 2006. Foundations of Bilingual Education and Bilingualism. 4th edition. Clevedon: Multilingual Matters.

Baker, Colin; Jones, Sylvia Prys 1998. Encyclopedia of Bilingualism and Bilingual Education. Clevedon: Multilingual Matters.

Baldauf, B. Richard; Kaplan, B. Robert 2006. Language Planning and Policy in Europe: the Czech Republic, the European Union and Northern Ireland. Clevedon: Multilingual Matters.

Bayley, Robert; Schecter, Sandra R. 2003. Language Socialization in Bilingual and Multilingual Societies. Clevedon: Multilingual Matters.

Broeder, Peter; Extra, Guus 1999. Language, Ethnicity and Education: Case Studies of Immigrant Minority Groups and Immigrant Minority Languages. Clevedon: Multilingual Matters.

Commission of the European Communities 2005. Communication from the Commission to the Council, the European Parliament, the Economic and Social Committee and the Committee of the Regions. A New Framework Strategy for Multilingualism. $\operatorname{COM}(2005) 596$ final. http://ec.europa.eu/education/policies/lang/doc/com596_ en.pdf (17.12.2009).

Conklin, Nancy; Lourie, Margaret 1983. A Host of Tongues. New York: The Free Press.

DfEE 1999. The National Curriculum Key Stages 1 and 2. DfEE, QCA: London.

Edwards, Viv 1996. The Other Languages: A Guide to Multilingual Classrooms. Reading, England: National Centre for Language and Literacy.

Eesti rahvaloendus 2000 = Eesti Statistikaameti rahvaloendus 2000. http://www.stat.ee// gatekeeper.stat.ee:800o/px-web.2001/Database/Rahvaloendus_regionaalne/Rahvaloendus_regionaalne.asp (17.08.2009). 
Fishman, Joshua A. 1991. Reversing Language Shift. Teoretical and Empirical Foundations of Assistance to Threatened Language. Clevedon, Philadelphia, Adelaide: Multilingual Matters Ltd.

Gans, Herbert J. 1997. Toward a reconciliation of 'assimilation' and 'pluralism': the interplay of acculturation and ethnic retention. - International Migration Review, 31 (4), 875-892. doi:10.2307/2547417

Giles, Howard; Bourhis, Richard Y.; Taylor, Donald M. 1977. Towards a theory of language in ethnic group relations. - Howard Giles (Ed.). Language, Ethnicity and Intergroup Relations. London: Academic, 307-348.

Giles, Howard; Byrne, Jane L. 1982. An intergroup approach to second language acquisition. - Journal of Multilingual and Multicultural Development, 3 (1), 17-40.

Goldenberg, Claude; Rueda, Robert S.; August, Diane 2006. Sociocultural contexts andliteracy development. - Diane August, Timothy Shanahan (Eds.). Developing Literacy in Second-language Learners. Report of the National Literacy Panel on Language-Minority Children and Youth. National Literacy Panel on Language-Minority Children and Youth (U.S.), National. Mahwah, New Jersey: Lawrence Erlbaum Associates, 247-346.

Helemäe, Leena; Plotkin, Aleksander; Semjonov, Aleksei; Vöörmann, Rein 200o. Identiteedi kujunemise probleemid post-sotsialistlikus keskkonnas (Tallinna rahvusvähemuste kogemuse alusel). Uuringu aruanne, Tallinn 1999-2000. Tallinn: Inimõiguste Teabekeskus.

Hoffmann, Charlotte; Ytsma, Jehannes (Eds.) 2003. Trilingualism in family, school, and community. Language Arts \& Disciplines. Clevedon: Multilingual Matters Ltd.

Holmes, Janet; Aipolo, Anahina 1993. The Wellington Tongan community: Prospects for language maintenance. - Wellington Working Papers in Linguistics, 1, 1-16.

Hudson, Alan 2001. Diglossia. - Rajend Mesthrie (Ed.). Concise Encyclopedia of Sociolinguistics. Oxford: Elsevier Science.

Hyltenstam, Kenneth; Stroud, Christopher 1996. Language maintenance. - Hans Goebl, Peter H. Nelde, Zdenek Stary, Wolfgang Wölk (Eds.). Contact Linguistics: An International Handbook of Contemporary Research. Berlin: Walter de Gruyter, 271-286.

Iskanius, Sanna 2005. Venäjänkielisten maahanmuuttajaopiskelijoiden kieli-identiteetti. Jyväskylä Studies in Humanities, 51. Jyväskylä: Jyväskylän Yliopisto.

Kaur, Sukhwant; Mills, Richards 1993. Children as interpreters. - Richard W. Mills, Jean Mills (Eds.). Bilingualism in the Primary School. London: Routledge, 112-129.

Kohnert, Kathryn; Yim, Dongsun; Nett, Kelly; Kan, Pui Fong; Duran, Lilian 2005. Intervention with linguistically diverse preschool children: a focus on developing home language(s). - Language, Speech, and Hearing Services in Schools, 36, 3, 251-263. doi:10.1044/0161-1461(2005/025)

Kohtla-Järve ametlik kodulehekülg. http://www.kjlv.ee/?lang=et\&page=commoninform ation/history (11.08.2009).

Komondouros, Markos; McEntee-Atalianis, Lisa 2007. Language attitudes, shift and the ethnolinguistic vitality of the Greek orthodox community in Istanbul. - Journal of Multilingual and Multicultural Development, 28, 5, 365-384. doi:10.2167/jmmd483.1

Krauss, Michael 1992. The World's languages in crisis. - Language, 68, 4-10.

Li, Peter S. 2001. The economics of minority language identity. - Canadian Ethnic Studies, 33 (3), 134-154.

Maardu linna ametlik lehekülg. http://www.maardu.ee/index.php?page=65\& (28.08.2009).

Mills, Jean 2001. Being bilingual: perspectives of third generation Asian children on language culture and identity. - International Journal of Bilingual Education and Bilingualism, 4 (6), 383-402.

Moon, Bob; Ben-Peretz, Miriam; Brown, Sally 2000. The Routledge International Companion to Education. London, New York: Routledge. 
Muldma, Maia (Ed.). 2009. Dialogue of cultures - possibility or inevitability? II. / Kultuuride dialoog - võimalus või paratamatus? II. Tallinn: Tallinn University Press.

Pavlenko, Aneta 2004. "Stop doing that, ja komu skazala": language choice and emotions in parent-child communication. - Journal of Multilingual and Multicultural Development, 25 (2, 3), 179-203. doi:10.1080/01434630408666528

Pedraza, Pedro; Pousada, Alicia 1992. Bilingualism in and out of school: ethnographic perspectives on the determination of language dominance. - Marietta Saravia-Shore, Steven F. Arvizu (Eds.). Cross-cultural Literacy: Ethnographies of Communication in Multiethnic Classrooms. New York: Garland Publishing, 253-272.

Piller, Ingrid 2002. Bilingual Couples Talk: the Discursive Construction of Hybridity. Amsterdam: John Benjamins.

Rannut, Mart; Rannut, Ülle; Verschik, Anna 2003. Keel, võim, ühiskond. Tallinn: Tallinna Pedagoogikaülikooli kirjastus.

Rannut, Ülle 2002. Muukeelsete õpilaste integratsioon eesti koolis. Kohtla-Järvel, Tallinnas, Valgas ja Sindis muukeelsete õpilastega töötavate õpetajate, muukeelsete õpilaste ja nende vanematega läbi viidud uuringu tulemused 20.03-08.05.2002. Tallinn: Mitteeestlaste Integratsiooni Sihtasutuse Haridusprogrammid.

Rannut, Ülle 2005. Keelekeskkonna mõju vene õpilaste eesti keele omandamisele ja integratsioonile Eestis. Tallinna Ülikooli humanitaarteaduste dissertatsioonid, 14. Tallinn: Tallinna Ülikooli kirjastus.

Rannut, Ülle; Rannut, Mart 2007. Tallinna õpilaste kodukeel. - Haridus, 3-4, 7-10.

Seville-Troike, Muriel 2000. Causes and consequences of language maintenance/shift. - Elite Olshtain, Gabriel Hornczyk (Eds.). Language, Identity, and Immigration. Jerusalem: The Magnes Press, Hebrew University, 159-171.

Shapiro, Daniel, M.; Stelcner, Morton 1997. Language and earnings in Quebec: trends over twenty years, 1970-1990. - Canadian Public Policy/Analyse de politiques, 23 (2), $115-140$.

Simpson, Alan 1991. The uses of "cultural literacy": a British view. - Journal of Aesthetic Education, 25, 4, 65-73. doi:10.2307/3332904

Siraj-Blatchford, Iram; Clarke, Priscilla 2000. Supporting Identity Diversity and Language in the Early Years. Buckingham: Oxford University Press.

Skutnabb-Kangas, Tove 2000. Linguistic Genocide in Education - or Worldwide Diversity and Human Rights? Mahwah, New Jersey: Lawrence Erlbaum Associates.

Starks, Donna 2005. The effects of self-confidence in bilingual abilities on language use: perspectives on Pasifika language use on South Auckland. - Journal of Multilingual and Multicultural Development, 26, 6, 533-550. doi:10.1080/01434630508668424

Zentella, Ana Celia 1999. Growing up Bilingual. Malden, MA: Blackwell.

Tuominen, Anne 1999. Who decides the home language? A look at multilingual families. - International Journal of the Sociology of Language, 140, 59-76. doi:10.1515/ ijsl.1999.140.59

Urzúa, Alfredo; Gómez, Edwin 2008. Home style Puerto Rican: a study of language maintenance and use in New England. - Journal of Multilingual and Multicultural Development, 29 (6), 449-466. doi:10.1080/01434630802147999

Vahtin 2004 = Вахтин, Николай 2004. Социолингвистика и социология языка. - Язык и общество. Санкт-Петербург: Гуманитарная Академия, 33-39.

Van Tuijl, Cathy; Leseman, Paul P. M.; Rispens, Jan 2001. Efficacy of an intensive home-based educational intervention programme for 4- to 6-year-old ethnic minority children in the Netherlands. - International Journal of Behavioral Development, 25, 148-159. doi:10.1080/01650250042000159

Verschik, Anna 2004. Koodivahetus meil ja mujal. - Keel ja Kirjandus, 1, 25-45. 
Wiley, Terrence, G. 1996. Language planning and language policy. - Sandra L. McKay, Nancy H. Hornberger (Eds.). Sociolinguistics and Language Teaching. Cambridge: Cambridge University Press, $103^{-147 .}$

Wong Fillmore, Lily 1991. When learning a second language means losing the first. - Early Childhood Research Quarterly, 6, 323-346. doi:10.1016/So885-2006(05)80059-6

Elvira Küüni (Tallinna Ülikool) peamised uurimisalad on Eesti venekeelse elanikkonna etniline ja keeleline identiteet, vene emakeelega õpilaste kohanemine eestikeelses üldhariduskoolis ja töökeskkonnas, Eesti vähemuskeelte arengutendentsid.

elvira.kuun@tlu.ee 


\title{
THE VIABILITY AND DEVELOPMENT TRENDS OF ESTONIAN MINORITY LANGUAGES IN SEGREGATIVE LANGUAGE ENVIRONMENTS
}

\author{
Elvira Küün
}

Tallinn University

The language policy of the European Union promotes diversity. Consequently, it is an important matter for Estonia as one of its member states to find out what the current language situation in Estonia is. It is necessary to get an overview of what languages the language minority groups in Estonia use in the public sphere and in informal communication, and whether there is a need to teach minority languages more extensively at Estonian schools. The government's education policy should take this information into account.

According to the Estonian population registry-the official source of information on what the people in Estonia claim to be their mother tongues-the 142 ethnic groups living in Estonia speak 109 different mother tongues (the biggest minority group is Russian). Unfortunately, the register does not contain more specific data: for instance on what languages are used at home, i.e. in the informal environment. The speakers of minority languages in Estonia are immigrants who have mainly come to live and work here in the industrial areas and are currently forming segregated groups. Although at present there are quite many Sunday schools operating in Estonia where the children of minority language group representatives are taught their mother tongue and their culture of origin, there still remains a threat to their languages' existence in Estonia. Common reasons for this are cultural pressure and the lower prestige the minority language has in the eyes of the speakers themselves. The speakers' number is not always decisive here-their attitude towards their mother tongue plays the main role in this case.

Language transfer between generations can be predicted from the primary school pupils' language use. Therefore, the language choices of the school pupils of this age and their parents were studied in the article. The results of the survey showed that the oral competence of the minority language group representatives in the minority language is better than their literacy. However, literacy has the key role in language maintenance. The non-Russian minority language speakers of the Estonian segregative language environments tend to assimilate in the Russian community. In order to slow down the assimilation process of different population groups the article suggests to consider offering facultative subjects on the minority language and culture at the schools where a sufficient number of children from a minority language are taught.

Keywords: education policy, language policy, language choice, language competence, home language, Estonian, Russian, other languages 